\title{
THE RETENTION OF ARABIC LANGUAGE AS A NATIONAL IDENTITY IN TWO OF GADAH AS-SAMMAN'S NOVELS: POSTCOLONIAL PERSPECTIVE
}

\author{
Mahmudah $^{1^{*}}$, Sangidu ${ }^{2}$, Fadlil Munawwar Manshur ${ }^{3}$ \\ ${ }^{1 *, 2,3}$ Universitas Gadjah Mada, Indonesia. \\ Email: ${ }^{1 *}$ mahmudah.arb@ugm.ac.id, ${ }^{2}$ sangidu@ugm.ac.id, ${ }^{3}$ fadlil@ugm.ac.id
}

Article History: Received on $28^{\text {th }}$ March 2020, Revised on $18^{\text {th }}$ May 2020, Published on $17^{\text {th }}$ June 2020

\begin{abstract}
Purpose: This article aims to analyze the retention of the Arabic language as a national identity by Lebanon nationalists who live as exiles outside European countries in two of her novels, Lailatul-Milyār and Sahrah Tanakkuriyyah LilMautā. As a product of fiction from a colonized country, both stories represent postcolonial discourses, showing the effect of colonialism, while also voicing resistance to colonialism.

Methodology: The research materials or material objects in this article are two of as-Sammān's novels. Data sources were grouped in primary data, which is the two of Sammān's novels, and secondary data, which is various references that support analysis, including books, journals, blogs, and other relevant sources in academic studies. Deconstruction is a textual strategy, which is utilized for analyzing the data in this study. No software tool is used.
\end{abstract}

Main Findings: The Lebanese nationalists in Europe tried to maintain the use of the Arabic language as the first and foremost national identity for several reasons, including defending (1) the Arabness, (2) the membership in the national community, and (3) the nation and nationality.

Implications/ Applications: This study highlights that resistance to colonialism can be done in various ways, both through violence and non-violence. In modern times, non-violent methods are frequently used. Among the non-violent ways is to fight for the retention of the Arabic language as a national identity so that to maintain it means to maintain Arabism, the membership of the nation's community, and defend the nation and nationality of the Arabs.

Novelty/Originality of this study: These findings highlight the struggle of the Lebanese nationalists in Europe; the younger generation who are trying to inherit Arabic must also struggle to learn it, both formal and informal, even against the mainstream. The results of persistence and perseverance in learning Arabic cannot be seen immediately, but a long time after that. The ability to speak Arabic, then, can foster a spirit of nationalism in the young Arab generation.

Keywords: Retention of Arabic Language, Postcolonial, Nationalism, Lebanon, Gädah As-Sammān.

\section{INTRODUCTION}

Arab countries have witnessed important political, social, and cultural events from the 16th century to the 1950s/1960s, which becomes a form of resistance to the western conquest ('Azm and Tal'at, 2015; Hilao, 2016). In modern history, there have been nakbah or 'disaster' and hazimah or 'defeat', which have greatly influenced the crystallization of Arab consciousness, becoming a hard blow that moves the feelings of the Arabs. Western colonialism as, well as imperialist European and American forces, are behind all these defeats. These events are reflected in Arabic literary works as a reaction that leads to the orientation of nationalism among the Arabs ('Azm and Tal'at, 2015).

Nationalism is the most vital force in the international political world in the $20^{\text {th }}$ century which, made a significant positive contribution to the adverse effects of World War II and led to the end of colonialism (Barrington, 2006). Nationalism is generally used to describe two phenomena, the attitude of a nation's concern for its national identity as a nation and the act of a country when looking for ways to achieve or maintain its destiny (Kellas, 1998). In the Middle East context, Suleiman (Al-Musawi, 2003; Pradhan, 2016) mentioned that the rise of Arab nationalism at the end of the $18^{\text {th }}$ century and the beginning of the $19^{\text {th }}$ century was expressed in literary works composed by Arab writers.

Understanding the complexity and richness of the narrative strategy of modern Arabic literature can be integratively done by utilizing the postcolonial perspective. Starting from the formation as a colonial subject and transferring power to the native elite in various ways and struggles, the postcolonial countries are still entangled in a long, complicated history of domination since the Ottoman Empire in 1517, the power of European nations, and neo-colonialism. Having past the colonial period and the Mandate, the culture in the Arab world grew and changed in dialogue and confrontation (Badawi, 1992). Postcolonial in modern Arabic literature can be traced from the statement of Badawi (1992), who considered that the adverse effects of World War I for the Arabs can be seen as sowing the seeds of many future problems. In facing this failed political aspiration of the desire to establish a free territory from Turkish control, novels that expressed resistance to the colonial power that represented nationalism emerged, both Arabic as a global and local language, which discussed the issue of independence and self-determination. Thus, it is reasonable that Al-Musawi (2003) stated that Nahdah writers throughout the Arab world believe in the power of the word to achieve transformation against colonialism. Postcolonial takes on current issues that have a history of the past. The colonials referentially remained and lived in the 
minds of Arabic fiction writers, not only in Egypt, but also in Jordan, Iraq, North Africa, and particularly the Middle East.

The relationship of the novel as a work of fiction with the nation as described by Brennan (1990) was that the story accompanied the rise of nations by objectifying the 'one, yet many' of political life, and by mimicking the structure of the government, which is Anderson's (2006) view is called an imagined political community. A government has at least five objective factors that can help in the identification of groups of it, including region, country, cultural language, and history (Suleiman, 2003). Regarding style, Dawisha (2003) added that nationalist narrators might disagree over the relative merits of other factors, but they all agreed on the centrality of Arabic as a unifying force. The role of Arabic as an essential element in shaping Arab national identity is the central theme of the literature on Arabic nationalism.

One of the writers who are very concerned with the above phenomenon is Gādah as-Sammān, a Syrian-Lebanese female writer, whom considered by Cooke(1988) as the best-known and most widely read of the 'Beirut Decentrist'. 'Beirut Decentrist' is defined by Cooke (1988) as 'a group of women writers who have shared Beirut as their home and the war as their experience'. In Starkey's (2008) view, they are considered as a unique phenomenon in the modern Arab world. Among Gādah as-Sammān (2018)'s novels are, which describe the lives of Lebanese immigrants in Switzerland and Paris. The characters were revolutionaries who fought for the Lebanese homeland and nation but were trapped in the Civil War until they were driven out of their homes. Although they live in exile with many difficulties in the host society, even threats from their state authorities, they still maintain a devotion to the Lebanese homeland as proof of their love. Among the severe problems felt by nationalists is the inability of young people to speak Arabic, even though it becomes a significant element to show their identity as Arabs.

\section{PURPOSE OF THE STUDY}

1. Why the retention of Arabic as a national identity is significant to Lebanese nationalists in exile,

2. How nationalists maintain Arabic as a national identity and the challenges they face, and

3. The effectiveness of efforts to sustain Arabic as a national identity in growing nationalism?

\section{LITERATURE REVIEW}

The close relationship between Arabic and nationalism in the colonialism perspective has been widely discussed by researchers, including its relationship with Arabization in the Arab world. Starkey (2008) explained the process of $t a{ }^{\prime} r \bar{b} b$, Arabization in Sudan, which involved the spread of Arabic identity and the Arabic language. During the decolonization of the 1950s, nationalists turned ta'rīb into an official policy that sharpened non-Arab and African characters and, in several places, accompanied by the growth of the ideology of culture and race supremacy of Arab. Bitar(2011) discussed the relationship of the Arabic language, identity, and nationalism in the Palestinian case by pointing out that the Arabic language is a crucial element in shaping its national identity. Meanwhile, the Levant Arabic spoken by Palestinians in the diaspora gives them a sense of identity and awareness of their shared cultural heritage. Al Allaq (2014) discussed Arabic in the United Arab Emirates in a globalized world that impacts on the Arabic language so that maintaining cultural identity becomes crucial. He also showed that globalization is a new form of colonization. He recommended the promotion of Arabic as a national treasure among the young Arab generation.

Efforts to spread the Arabic along with its culture, in some instances, for example, in Sudan, raise the gap between Arabic and non-Arabic. However, in the case of Palestine, Arabic has become an essential element in shaping the country's identity as an Arab nation. Meanwhile, a country that gets the adverse effects of globalization, such as the United Arab Emirates, has problems in competing Arabic with foreign languages, in this context, English. Their concern is on the younger generation who are vulnerable to the adverse effects of globalization, which can be regarded as a new form of colonialism. Therefore, the inheritance of the Arabic to the younger generation must be done as an effort to maintain the Arabic as the identity of the Arabs (Anderson, 2006; Mackey, 1937; Setiawati, 2010). In the context of the inheritance of the Arabic language to the young generation, a meeting point was found with the issues discussed in this article. While this phenomenon serves a literary fact in this study, it was a social fact in the previous ones (Al Allaq. 2014).

In the context of literary works, there are also quite a lot of discussions about the representation of nationalism. Hout(2006), for example, discussed the problematic conditions of in-betweenness in contemporary exile Lebanese novels that show the relationship between exiles and nations. Among the discussions are the three main elements of memory that function as 'emotional channels to the motherland', including language (in the slip phenomenon to Arabic), culture (in paintings), and history (in dreams) of the original characters. However, the discussion is still general, not paying attention in detail to the role of the Arabic language as one of the building elements of Arab national identity. The retaining of the Arabic language as a national identity in fiction, especially in two of as-Sammān, s novels in this article, can enrich how Arab writers connect the word with their nationalism.

Given this, this study aims to shed light on the struggle of Arabic nationals who are living in a foreign land. 


\section{MATERIALS AND METHOD}

The research materials or material objects in this article are two of as-Sammān's novels Gandhi, 2001. Since the formal objective is related to the postcolonial perspective, therefore, it is also associated with the postcolonial aspect in the material objects. The postcolonial element found in these material objects is the retention of the Arabic language as a national identity. The issue of retaining the Arabic language as a national identity by the Lebanese people in two of Sammān's novels will be analyzed from the perspective of postcolonial literature. Foulcher and Day (2002) stated that the postcolonial approach in the research is a reading strategy that considers and identifies the signs, effects of colonialism, and their impact in literary texts, and the position of the postcolonial writer as a person and his/her narrative voice. Postcolonial theory bases on the concept of otherness. The colonized subject is characterized as 'other' through discourses such as primitive and cannibal, which meant affirming the binary separation between colonizer and colonized and emphasizing the superiority of colonization culture (Gandhi, 2001). Gandhi (2001) underlined that regardless of the definition is given to the post-colonial must be seen from its ability to conceptualize complex conditions due to the awful colonial occupation.

\section{Method of Collecting Data}

Data collection was based on the work of literature study methods. The method was carried out by (1) paying attention to words, phrases, sentences, or paragraphs in the two of Samman's novels that show the issue of retaining the Arabic language, and (2) grouping words, phrases, sentences, or paragraphs according to their classification. Data sources were grouped in primary data, which is the two of Sammān's novels, and secondary data, which is various references that support analysis, including books, journals, blogs, and other relevant sources in academic studies.

\section{Method of Data Analysis}

The method of data analysis that was used to discuss the issue of retaining the Arabic language as a national identity in this article was Derrida's deconstruction. Deconstruction is a textual strategy in reading texts by looking for the 'implicit' in the text. Thus, the obtained data in the form of speeches, thoughts, and behaviours of the characters of the novels are analyzed based on the postcolonial perspective by linking them with relevant secondary sources.

\section{RESULTS AND DISCUSSION}

\section{Colonialism, the Civil War, and Emigration}

French troops occupied Lebanon and Syria in 1918 and have ruled the area as the League of Nations mandate (Shapiro, 1984; Khoury, 1989) from 1920. Under the Mandate, France was supposed to manage Greater Syria, including Lebanon, until the country became independent. However, France had other ideas and instead separated Lebanon from Syria and enlarging Lebanese territory. Maronites strongly agreed on the French Mandate and formed a majority group on Mount Lebanon (Shapiro, 1984). Maronites prefer France because they believe that in the past, Muslims and Turks had deliberately made Maronites suffer. That is why sectarian issues cannot be avoided in the Lebanese region (Petran, 1987). Muslims assume that the French Mandate is tantamount to a new Crusader state because they seized the territory of the Muslim population (Mackey, 1937). After taking control of Greater Lebanon, France rejected the Arabian side of Lebanon and began its civilization mission. They made a French version of Lebanon in which all life cycles such as education and the economic system were carried out in the French way. The new Lebanese entity is divided between two fundamental groups: one is looking West, while the other is the opposite. Thus, the confrontation between Islam and the West entered a new phase (Mackey, 1937).

Lebanon declared independence on November 26, 1941 (Foster, 1992). The journey of Lebanese independence did not go smoothly because of the interference of France and the various political conflicts that accompanied it (Yulianto, 2010). France certainly will not just let Lebanon go before leaving Lebanon. Therefore, an agreement was called a National Pact 1943. It — which is far from being called a national—was only an oral agreement between representatives of Maronite and Sunni groups for their interest in the distribution of power (Dahir, 1984). The core of Lebanon's policy into Lebanon itself and towards the Arab world is contained in the principles of the 1943 National Pact (Zisser, 2000). In general, the Lebanese President tends to defend the 1943 National Pact because it is more favourable to the Maronite Christian political power. However, this group rejected the other 1943 National Pact clause, which involved a ban on political affiliation with other countries, while they were naturally closer to France and other Western countries (Setiawati, 2010).

France left Lebanon in 1946 without changing Lebanese ethnicity to European or deciding French being the primary language. Lebanese residents, both Christians, and Muslims, still consider themselves as Arabs (Setiawati, 2010). The ongoing conflict culminated in the Civil War. Lebanon, especially South Lebanon, is an arena of conflict in competing interests between Lebanon with Iran, Israel, Syria, Palestine, America, and the international agenda (Nasrallah, 1992), and is the arena for a new Arab struggle (Goldschmidt\& Davidson, 1979; Sharkey, 2008). The instability of political life led to a wave of migration outside Lebanon. Tabar (2010) noted that throughout modern history, Lebanon had experienced at least four waves of emigration. The fourth wave occurred during the Lebanese Civil War (1975-1989), which destroyed Lebanon and its economy and hundreds of thousands of people emigrated. Cooke (1996) mentioned that as the people of the colonized countries, many Lebanese see that emigration is a solution for economic interests. 
In the novel, the Lebanese Civil War is exacerbated by Israel's presence in Southern Lebanon, causing suffering and making many Lebanese leave their homeland. Nationalist figures who eventually had to become outcasts in Europe reflected on the condition of the Lebanese homeland, especially the revolution that turned into a Civil War, as the following quotation shows.

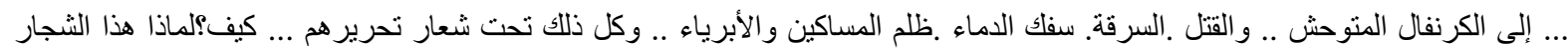

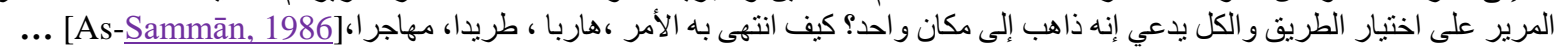

... become a wild carnival... murder, theft, bloodshed, the tyranny of the poor, and good people, all of which are under the slogan of their liberation. How? Why is this fierce quarrel (taking place) in choosing a path, while each thinks he/she is going to the same place? How did this problem end with his/her becoming a runaway, driven out, and left the motherland ...

Lebanese people living outside their homeland are in a dilemma between choosing to live in the Lebanese homeland or their new holland (Mahmudah, 2018). Both novels show that Lebanese people, especially nationalists, are concerned about cases, which show that the younger generation of children from the first generation of the 1990 Civil War who lived in exile in Europe generally could not speak Arabic. For nationalists, not being able to speak Arabic is a matter of great concern given the close relationship between Arabic and their national identity as Arabs. Language, according to Barakat (2012), together with culture, socio-political experience, economic interests, and collective memory, related to one's position and role in history, as the basis of Arab nationalism sentiments. Husri in Suleiman (2003) stated that Arabic as the language of national identity must be a unified and unifying language.

\section{The New Generation and the Spirit of Retaining Arabic}

The concerns of the nationalists are reasonable, given that they live in a French-speaking country. The new generation was born from families with different backgrounds who, at the same time, show the level of their nationalism. The following description will show that the degree of nationalism of parents influences the spirit of inheritance of Arabic for the next generation.

\section{The generation born from intermarriage between Arabs and Non-Arabs}

Many Lebanese emigrate and do not return to their homeland. Among them are even married to local people and have children who do not know Arabic at all. Because they do not know Arabic any further, they are further away from knowing their nation and homeland so that the spirit of nationalism is feared to disappear.

The case of mixed marriages between Arabs and non-Arabs is found in the novel Lailatul-Milyār (1986), which bonds Laila, a Lebanese woman, and a French man from whom the marriage was born Maryam. Lailā's mother refused the marriage and was furious when Maryam followed her father's nationality after Lailā's divorce. Maryam was raised by her father with his culture and language. When her father died, Maryam returned to her mother's house. However, the grandmother and grandchildren cannot communicate with each other because they cannot understand the language they speak. Lailā recounted the difficulty of her mother and her daughter in communicating with Amīr, a nationalist figure.

$$
\text { [ As- Sammān,].بكت طويلا يوم عادت إلينا مريم و اكتثفت أنها هي أيضا لم تعد تعرف العربية . كان أمرأ بائسة أن ألعب دور المترجم بين أمي و ابنتي }
$$

'Mother cried for a long time the day Maryam returned to us and learned that Maryam could not speak Arabic. It's so sad that I played the role of a translator between my mother and my daughter.'

Maryam also preferred a French man, Frederick, and lived with him rather than living with her grandmother and mother. The difficulty of communicating between herself and her grandmother was told by Maryam in French to Amīr, a nationalist figure.

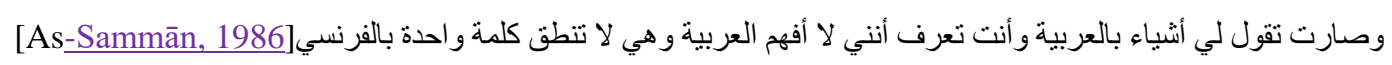

'She (grandmother) started talking to me a lot of things in Arabic, even though you know, I can't speak Arabic, while grandma didn't know a word in French at all.'

Thus, it is reasonable that nationalists are always worried about the phenomenon of intermarriage between Arabs and non-Arabs, that in turn, can shift Arabic as a daily speech-language, lessening the feelings of being Arabs.

\section{The generation born in Europe from the marriage of fellow Arabs}

Among the migrants are Lebanese who were married before leaving the country. Some of them gave birth to a generation that could not speak Arabic because their parents did not regard the inheritance of Arabic as something important. It is possible because parents are not included in the nationalist group who have a concern about the condition of the nation and the motherland.

This case was found in the family of Nadīm and Dunyā in Lailatul-Milyār (1986). Both are Lebanese who have legalized their marriage before going to Switzerland to get a better economic life. Ideologically, Nadīm was not among the nationalists. On the contrary, he was among the Lebanese who made the Civil War worse in Lebanon by sending 
weapons to the warring parties. Meanwhile, his wife, Dunyā, despite her concern for the fate of her homeland, could not do much to improve the Arabic language of her children.

$$
\begin{aligned}
& \text {...فجأة صبي جميل خاطب دنيا بالفرنسية دون أن يلتفت إليه ثم انسحب بسر عة... } \\
& \text { ـ هذا ابني باهر. إنه للأسف لا يتكلم العربية كابنتي .... لقد ولدا وكبرا هنا. }
\end{aligned}
$$

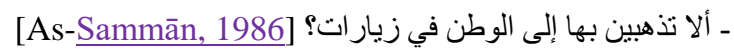

'...., suddenly a handsome boy spoke in French to Dunyā without turning to him (Khalīl) and then disappeared quickly as well.

'That is my son, Bāhir. Unfortunately, he could not speak Arabic, as did my daughter. They were born and raised here.'

'Didn't you bring her to the homeland during your visits?'

Possibly, their inability to speak Arabic is because they are practically faced with interactions that require the ability to speak the local language, French. Meanwhile, their parents did not take any action to transfer Arabic to the generation. Thus, they are also difficult to establish communication with extended families in the homeland, which in turn cut off relations with people in the homeland.

\section{The generation that was born in Lebanon and grew up in Europe from a marriage of fellow Arabs}

The next-generation model was born to families with children who were born in Lebanon during the Civil War and grew up in Europe. This example is the case of Danā and Fawwāz. Danā is the daughter of Sulaimā, while Fawwāz is the son of Fā'iz, the nationalist in the Sarah Tanakkuriyyah lil-Mautā. Although both of them go through life with almost the same situation, both have different Arabic language skills. It can be said that this generation can be grouped into two, which are (1) generations born from non-nationalist groups, and (2) generations born from nationalist groups.

The generation born from non-nationalist groups is Danā, who speaks French and cannot speak Arabic except for a few terms. Like Bāhir and his sister, Danā and two of her sisters in Lailatul-Milyār (1986) also came from the marriage of fellow Lebanese Arabs who were preoccupied with achieving high socioeconomic status. However, Sulaimā, Danā's mother, still has concerns about the inability of her children to speak Arabic even though she cannot handle it.

$$
\text { طالع يا فو از. حافظ على لغتلك العربية من النسيان. لا تفعل مثل دنا و أختيها] [Mahmudah, 2003 . }
$$

(Sulaimā said to Fawwāz): "Read (the newspaper), Fawwāz. Don't forget your Arabic. Don’t be like Danā and two of her sisters"

Sulaimā's sentence is intended to insinuate her daughter, Danā, and two of her sisters, who are not willing to learn Arabic. Therefore, when there were Arabic-language newspapers they found at the airport, Fawwāz was the one who was asked to read them. As for Danā, because she could not speak Arabic, she had a fear when visiting her homeland, Lebanon.

كانت خائفة قليلا ، كعادتها كلما زارت بيروت مع أمها! فكيف تلوم مدعوتها الغريبة التي لا تنطق بكلمة عربية واحدة غير:

[Mahmudah, 2003]" النجدة"

'Danā felt frightened as usual whenever she visited Beirut with her mother. How does she reproach the foreign woman she invited (Mary Rose) who cannot speak a single Arabic word except 'help'?

Because Danā did not know Arabic as well as the people in her homeland, a visit to Beirut was not pleasant. On the contrary, it was torture. She needs a strong reason to come to Beirut, which is cosmetic surgery.

The generation born from nationalist figures has concerns about Arabic because they are educated by their parents who have high nationalism. Therefore, they have the awareness to teach Arabic to their children. This case occurred in the Fawwāz family in the Sarah Tanakkuriyyah lil-Mautā (2003). Fawwāz was born in Lebanon in the Civil War, then grew up and lived in Europe. His father, Fā'iz, was forced to leave the Lebanese homeland with his family because he continued to be hunted down by parties who were fighting along with the Israeli invasion of South Lebanon. Fā'iz fought hard to make Fawwāz speak Arabic during circumstances and conditions that were less supportive of someone having to speak Arabic. In exile, Fawwāz was encouraged by his parents to learn Arabic, especially formally in an educational institution.

والده يصطعبه ثلاث مرات في الأسبوع و مساء إلى الددرسة العربية في باريس ، مدرسة مايا ضاهر ، حيث يتعلم لا وينظره في الدقهى

[As-Sammān, 2003] المجاون

"His father (Fāiz) accompanied him three times a week to an Arabic language teacher in Paris, Māyā Ḍahir, whom Fāiz learned the language of his ancestors, while the father waited for him in the café next to it ...”

\section{Nationalist Efforts to Defend Arabic}

The young generation of nationalist families has a willingness to learn Arabic because of the encouragement of their nationalist parents. However, in both novels, such generations are very few. Seeing the phenomenon of the lack of 
ability of the young generation in Arabic, the nationalists called for the following two things, (1) avoiding marriage with non-Arabs, and (2) inherit Arabic for the next generations.

\section{Avoiding marriage with non-Arabs}

In both novels, nationalist figures such as Amīr and Khalīl are concerned about the intermarriage of the Lebanese Arabs with foreigners; in this context, it is France. Many male figures in both novels such as Sakhr, Ragīd, Watfān, Saqr, and Nadīm establish relationships with foreign women, including female characters, Lailā, who marries a French man. As for nationalist figures such as Amīr, Khalīl, and Hilāl, are not willing to deal with foreign women. They are greatly concerned about intermarriage because in the long run it has been proven that the children of intermarriages cannot speak Arabic, and thus lose the connection with their homeland.

$$
\text { المأساة أنهم لا يعودون بعد ذلك إلى الوطن .. معظمهم لا يعود. يتفرجون وييقون في أوروبا ويتزوجون وينجبون أو لادا لا ينطقون كلمة عربية }
$$

[Tabar] rärة

'A tragedy that they afterward did not return to their homeland. Most did not return ... scattered and lived in Europe, married and gave birth to children who could not speak a word of Arabic.'

The quote above shows the concern of nationalist figures about the future of Arabic in future generations. It is feared that they will no longer know Arabic so that they will lose their Arab nationalism. For nationalist figures, people who have no connection between themselves and their national language will slowly lose their nationality. Usually, people who do not care about their national language do not care about their homeland and its people. The case of Maryam in Cooke (1986) shows that someone who cannot speak Arabic tends not to communicate with people who speak Arabic even though they are a close family. Maryam finally prefers to live with Frederick, her French male friend because she also chose France as her nationality.

\section{Inherit Arabic for the next generation}

Nationalists see that the generation of their children who live outside the homeland, both those born in the homeland and exile, tend to not speak Arabic. It is understandable considering that the generation lives in an environment that does not use Arabic as a daily speech-language. In both novels, both in Switzerland and Paris, the generation tends to use French, the everyday language of the people living in the two countries. Therefore, nationalists consider the need to transfer Arabic to the next generation.

The act of preservation and inheritance of Arabic done is, for example, by reading Arabic newspapers or magazines. Fawwāz recounted his father's efforts to send him to an Arabic language school, including continuing to encourage him to buy and read Arabic newspapers. In addition to maintaining his Arabic language, reading the Lebanese newspaper also contributes to the continuation of his ties with the Lebanese homeland. As a nationalist figure, his father not only encouraged his son to learn Arabic but also maintained his Arabic by reading Arabic texts.

$$
\text { [As-Sammān, 2003] وير افقه إلى مدرسة تعلم العربية ويعيده منها في شتاء باريس القارس }
$$

'He (Fā'iz) accompanied him (Fawwāz) to the Arabic language school and picked him up from there in the bitter winter of Paris, waiting for him at the door of the school or the side cafe while reading an Arabic newspaper.'

It can be seen that the nationalist figure has a high enthusiasm for passing Arabic to the next generation. He must fight to make the next generation able to speak Arabic in a country that does not use Arabic as the language of daily communication. The use of Arabic continues to be championed and passed down by nationalists to the next generation. It is very reasonable since the use of Arabic is considered one of the conditions for someone remains to be called an Arab.

\section{The Effectiveness of Maintaining Arabic As A National Identity}

This section will discuss the effectiveness of maintaining Arabic in fostering a spirit of nationalism. The young generation hardly feels the benefits of learning Arabic in their learning process because they live in an environment that does not use Arabic in their daily lives. They live in French communities. However, they felt a strong effect when they visited their homeland. Based on the events that occur in the young generation related to the use of Arabic, it is known that the use of Arabic gives the effect of feeling attached to the interlocutor as a member of the same community. Opponents who were initially foreign to the speaker, suddenly feel closer and feel like a part of each other. Before speaking in Arabic, there are feelings of fear, worry, anxiety, and isolation. On the contrary, after speaking in Arabic, feelings of calm, pride, and love emerge. Events that showed this change of feeling occurred when the younger generation visited their country, as shown by Fawwāz at the airport with security officers, Fawwāz with Khal̄̄l, Fawwāz with Samīrah, Danā with Nabīl, and Sulaimā with Walid.

The first generation who did not learn Arabic met with young nationalists who were very concerned about their homeland and nation and always spoke Arabic to the friends in their neighbourhood happily. Danā, who knew very little Arabic, was amazed at Nabīl and fell in love with his homeland, Lebanon. She realized her mistake for not learning 
Arabic and admired Nabīl, a young Lebanese doctor who had dedicated his profession to the poor and Palestinian refugees in Lebanon.

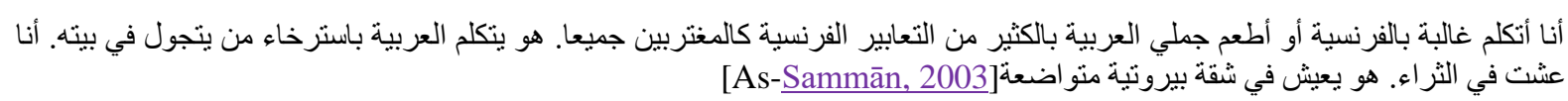

'I speak mainly in French or mix my Arabic sentences with many French expressions like all expatriates, while he speaks Arabic casually at his home. I live in luxury, while he lives in a simple apartment in Beirut'

Danā, who originally did not love Nabīl, and felt strange about the way of life he chose, loved him because of the Arabic language he always spoke. Danā felt a closeness to Nabīl at the same time she felt a closeness to his homeland as if she rejoined her community after a long separation. The same feeling was felt by Fawwāz when interacting with officers at the airport.

و حين سأله موظف الأمن بالفرنسية عن غرضه من الزيارة وهو يقلب جواز سفره الفرنسي. قال له بالعربية: أثتقت إلى بلدي. ابتسم الموظف

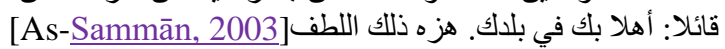

'When security officers questioned him in French about the purpose of his (Fawwāz) visit while flipping through his French passport, Fawwāz answered in Arabic: "I miss my country." The employee smiled.

"Welcome to your country." The employee's gentleness warmed Fawwāz's heart.

It also happened when Fawwāz first met Khalīl, a nationalist figure, Samīrah's father. Samīrah was Fawwāz's lover. Previously, he felt uneasy and worried, but after speaking in Arabic, he felt a sense of pride in front of a nationalist who had experienced exile like her father. He is proud to have learned Arabic in exile and on his visit to Lebanon, he can now communicate with him and demonstrate his ability to speak Arabic.

$$
\text { وقال لفو از: خذ .. وقرا .... قالت لي سميرة أنك تقرا أبالعربية] As- }
$$

"Take and read it! Samirah told me that you could read in Arabic."

Fawwāz also felt proud when he showed Samīrah that he prioritized Arabic among other foreign languages he had learned while in exile. He chose Arabic as the second foreign language after English. It fascinated Samirah because she realized how hard Fawwāz's struggle to learn Arabic in exile. Samīrah was someone who loves the motherland who was not willing to leave Lebanon even though all young men dream of leaving Lebanon.

أخبرها ذلك كله وبدت سميرة مبهورة وأخبر ها أنه فيما بعد اختار العربية كلغة ثانية إلى جانب الإنكليزية في البكالوريا الفرنسية بدلا من الألمانية

[As-

"He (Fawwāz) told Samīrah that he used to choose Arabic as the second foreign language besides English at the French undergraduate level, rather than German and Spanish."

Speaking Arabic also fosters a sense of love between the speaker and the interlocutor who still feel distant. Sulaimā, who had recently known Walīd and was in love, felt a closeness after Walīd recited poems in Arabic. Initially, they did not know each other even though they both lived in France and had only just met in Lebanon and then loved each other. They felt how Arabic was closer to their hearts than when they spoke in French.

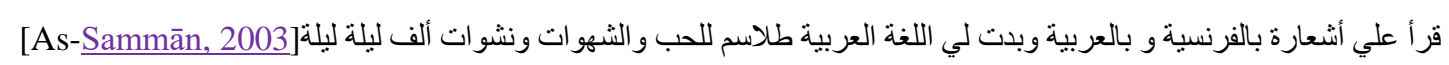

'He (Walīe) recited for me (Sulaimā) poems in French and Arabic. It feels to me that Arabic is like a spell of love, lust, and enjoyment of A Thousand and One Nights and an ancient world full of enchanting pleasures'

Although Sulaimā was not among the young generation, in the novel, she was told as if finding her youth again while visiting Lebanon and meeting Walīd, a young man much younger than her. Arabic seems to return them to their original habitat, to their homeland.

\section{Retention of Arabic in the Framework of National Identity}

The efforts of nationalists to educate young people to learn Arabic shows an effort to resist colonialism, remembering that one of the agendas of colonialism is the destruction and annihilation of the language of the people they colonized. Moreover, the nationalist figures in this novel live in countries that have colonized their country. Language and its frequency of use are the first things to be destroyed to ensure that national identity is destroyed (Al-Allaq, 2014). Considering that, retention of language as identity becomes something crucial for the struggle to defend the sovereignty of the nation and state.

Both novels show the efforts of Arab nationalists in maintaining Arabic as a national identity. The Gadah 2018 shows the efforts of nationalists of the Civil War generation in exile, while the Sarah Tanakkuriyyah lil-Mautā (2003) shows the results of their upbringing, children of the first generation. There is a difference in the spirit of maintaining Arabic between the two generations, where the first generation is trying harder to maintain Arabic. As for the next generation, they are not so eager to defend Arabic because they live in an environment that does not speak Arabic. However, during their visit to Lebanon from exile, they found a spirit of love for the motherland after interacting with the Lebanese 
people in the country. Thus, the use of Arabic triggers a spirit of nationalism whose greatest aim is 'tahqiqu al-wihdah al- 'Arabiyyah any-Syāmilah' 'realizing Pan-Arabism'(Gan̄̄, 1994).

Language is a sign of par excellence of Arab national identity. Something that makes an Arab remains Arab is his/her membership in the Arabic-speaking community (Suleiman, 2003). Rodinson (1981) mentioned that the Arabic language the first criterion when discussing 'who is Arab?' and that the ideology of Arabism has put language as a universally valid criterion. Furthermore, Husri (1985) stated Inna Kulla any-syu'ūbi al-latī tatakallamu al-'Arabiyyah -Kulla asysyu'ūbi an-națiqah bi aḍ-Dādi -hasbat-ta'bìri al-masyhüri, hiya 'Arabiyyah' all nations that speak Arabic - all nations that speak $D \bar{a} d$ - as the well-known expression for Arabic, are Arabs.' Nationalists worried that the inability to speak Arabic of the next generations can be a trigger for the loss of the Arabic identity of the Arab people in exile. Thus, the retention of Arabic is an attempt to maintain the Arab identity of Arab people.

The use of Arabic as a language of communication between members of the community creates the "imagined political community" (Anderson, 2006) - which presupposes a community whose members do not know each other and are limited by a boundary - to be real. Community members who did not know each other, after speaking in Arabic, felt a closeness. Previously, they were individuals who did not know each other. However, after speaking in Arabic, they felt there was a bond with each other. They feel rejoined in the group or habitat that they had long separated from them. Thus, language retention guarantees individuals to remain members of the nation's community where members use the same language.

The concern of nationalists can also be understood that language is the national identity of a nation. It is as stated by Suleiman (2003) that a nation is often associated with language as a marker of its identity and that language is the soul and life of the nation (Anderson, 2006). Language must be maintained with various efforts to preserve its identity as a nation. Language life means the life of the nation and the nationality of its people. On the contrary, its death is the death of the nation and its people. Thus, defending Arabic means defending the Arabic nation and nationality.

\section{CONCLUSION}

Resistance to colonialism can be done in various ways, both through violence and non-violence. In modern times, the methods of violence are considered ineffective so that non-violent methods are considered as the possible alternative. Among the non-violent ways is to fight for the retention of the Arabic language as a national identity so that to maintain it means to maintain Arabism, the membership of the nation's community, and defend the nation and nationality of the Arabs.

Retaining the Arabic language as a national identity is not an easy job to do, on the contrary, it requires serious effort and struggles from many parties, both individuals and holders of power who can act politically. Only individuals with a nationalist spirit are generally able to do so because they are well aware of the importance of their language as an element of nationalism. Nationalists are not only struggling to pass Arabic on to the next generation of youth but are also struggling with preserving Arabic by giving examples of how to preserve it. They show serious struggle, patience, and courage to take actions that others don't do. They realize that many young people have been separated far from Arabic for various reasons. First, they live in a country that does not use Arabic in daily communication. Second, globalization is so strong that it shifts Arabic and places foreign languages as a language of communication. Meanwhile, the younger generation who are trying to inherit Arabic must also struggle to learn it, both formal and informal, even against the mainstream. The results of persistence and perseverance in learning Arabic cannot be seen immediately, but a long time after that. The ability to speak Arabic, then, can foster a spirit of nationalism in the Arab young generation.

\section{LIMITATION AND STUDY FORWARD}

This study focused on retaining the Arabic language as a national identity; however, some limitations are there which must be addressed in the future. This study investigated the problem in light of two of Sammān's novels. Authors believe that the findings of this study can be made more comprehensive if a broader set of literature is used in analysis. Moreover, future researches can add viewpoints of the existing expatriates through interviews and survey to enhance the reliability of findings.

\section{ACKNOWLEDGEMENT}

This article is part of my doctoral research program at Gadjah Mada University, Indonesia, which is funded by the LPDP (Indonesian Endowment Fund for Education), Ministry of Finance of the Republic of Indonesia. Therefore, I would like to thank LPDP and my supervisors, Prof. Dr. Sangidu, M. Hum., and Dr. Fadlil Munawwar Manshur, M.S.

\section{AUTHORS CONTRIBUTION}

Mahmudah formulated the initial draft, Sangidu collected data, analyzed and interpreted results. Whereas, Fadlil Munawwar Mansur worked on the final manuscript and its proofreading. 


\section{REFERENCES}

1. Al-Allaq, W. (2014). Arabic Language in a Globalized World, Observations from the United Arab Emirates.Journal of Arab World English Journal, 5(3) 113-123.

2. Al-Musawi, M. J. (2003). The Postcolonial Arabic Novel: Debating Ambivalence. Brill, Leiden.

3. Anderson, B. (2006). Imagined Communities Reflections on the Origin and Spread Nationalism, Verso, New York

4. As-Sammān, G. (1986). Lailatul-Milyār, Mansyūrāàt Gādah as-Sammān, Beirut.

5. Azm, A., \&Ṭal'at, A. A. (2015).Adab Mā Ba da al-Isti 'mār wa Nazariyyatuhu an-Naqdiyyah. Ain li ad-Dirāsāt wa al-Buhūì al-Insāniyyah wa al-Ijtimā iyyah, Giza.

6. Badawi, M. M. (1992). Modern Arabic Literature.University of Cambridge, New York, 1992.

7. Barakat, H. (2012). The Arab World: Society, Culture, and State. Nusa Media, Bandung.

8. Barrington, L. W. (2006). After Independence: Making and Protecting the Nation in Postcolonial and Postcommunist States. University of Michigan Press, Ann Arbor. https://doi.org/10.3998/mpub.126246

9. Bitar, S. I. (2011). Language, Identity, and Arab Nationalism: Case Study of Palestine. Journal of Middle Eastern and Islamic Studies (in Asia), 5(4), 48-64. https://doi.org/10.1080/19370679.2011.12023190

10. Brennan, T. (1990). The National Longing for form in Nation and Narration.Routledge, London, 1990.

11. Cooke, M. (1996). Women and the War Story.University of California Press, London, Berkeley, Los Angeles, 1996.

12. Cooke, M. (1988). War's Other Voices: Women Writers on the Lebanese Civil War, Cambridge University Press, Cambridge.

13. Dahir, M. (1984). Lubnān al-Istiqlāl, aś-Siqah, wa al-Mïs̄äq, Dar al-Matbu'at asy-Syarqiyyah.

14. Dawisha, A. (2003). Arab Nationalism in the Twentieth Century: From Triumph to Despair, Princeton University Press, Princeton.

15. Foster, L. M. (1992). Enchantment of the World Lebanon, Children's Press, Chicago.

16. Foulcher, K., \& Day, T. (2002).Clearing a Space, Sastra Indonesia Modern: KritikPostcolonial,KITLVand YayasanObor Indonesia, Jakarta.

17. Gādah, S. (2018). Khitāb Mā Ba'da al-Isti'mār fì Majmü'ah Buhüs. Aceh: IMLA dan UIN ar-Raniry Banda Aceh, 839-848.

18. Gandhi, L. (2001). Postcolonial Theory a CriticalIntroduction.Kalam, Yogyakarta.

19. Ganī, M. A. (1994). Al-Ittijāh al-Qaumī fĩ ar-Riwāyah, al-Majlis al-Wațanī lis̀-Ṡaqāfah wa al-Funūn wa alĀdāb, Kuwait.

20. Goldschmidt, A., \& Davidson, L. (1979). A Concise History of the Middle East, American University in Cairo Press, Cairo, Egypt.

21. Hilao, M. P. (2016). Creative teaching as perceived by English language teachers in private universities. Journal of Advances in Humanities and Social Sciences, 2(5), 278-286. https://doi.org/10.20474/jahss-2.5.4

22. Hout, S. C. (2006). The Predicament of in-betweenness in the Contemporary Lebanese Exilic Novel in English" in Literature and Nation in the Middle East edited by Yasir Suleiman and Ibrahim Muhawi, Edinburgh University Press, Edinburgh. https://doi.org/10.3366/edinburgh/9780748620739.003.0011

23. Husṣri, S. (1985). Árā’ wa Aḥ̂adis fi al-Qaumiyyah al- 'Arabiyyah, 7, Markaz Dirāsāt al-Wiḥdah al-'Arabiyyah, Beirut.

24. Kellas, J. G.(2003). The Politics of Nationalism and Ethnicity. Palgrave, London, 1998. https://doi.org/10.1007/978-1-349-26863-4

25. Khoury, P. S. (1989). Syria and the French Mandate. Princeton University Press, New Jersey. https://doi.org/10.1515/9781400858392

26. Mackey, S. (1937). Lebanon (A House Divided), W. M. Norton \& Company, London.

27. Mahmudah (2003). Al-Mauqi'u al-Bainiyyu min al-Mugtaribīn al-Lubnāniyyīn fỉ Aurūbā fì Riwāyati Gurbatun Tahta as-Sifr li

28. Nasrallah, F. (1992). The Question of South Lebanon, Centre for Lebanese Studies, Oxford.

29. Petran, T. (1987). The Struggle over Lebanon, Monthly Review Press, New York.

30. Pradhan, S. (2016). English language teaching: The next gate to social awareness. International Journal of Humanities, Arts and Social Sciences, 2(4), 156-158. https://doi.org/10.20469/ijhss.2.20005-4

31. Rodinson, M. (1981). Les Arabes.The University of Chicago Press, Chicago. https://doi.org/10.5771/05067286-1981-4-460

32. Setiawati, S. (2010). A conditional mechanism in Lebanese internal conflict resolution, Elmatera Publishing, Yogyakarta.

33. Shapiro, W. E. (1984). Lebanon, Frankin Watt, New York, 1984.

34. Sharkey, H. J. (2008). Arab Identity and Ideology in Sudan: The Politics of Language. Ethnicity, and Race, African Affairs, 107(426), 21-43. https://doi.org/10.1093/afraf/adm068

35. Starkey, P. (2006). Modern Arabic Literature, Edinburgh University Press, Edinburgh.

36. Suleiman, Y. (2003). The Arabic Language and National Identity: A Study in Ideology. Edinburgh University Press, Edinburgh. 
37. Tabar, P. (2010). Lebanon: A Country of Emigration and Immigration. LAU Press, Beirut.

38. Yulianto, M. A. (2010). Lebanon (Pra-dan Pasca-Perang 34 Hari Israel vz Hizbullah), Gramedia, Jakart.

39. Zisser, E. (2000). Lebanon the Challenge of Independence, St Martin's Press, New York. https://doi.org/10.5040/9780755612574 